\title{
Original article \\ Evaluation of the lumbar multifidus in rowers during spinal stabilization exercise
}

\author{
Joseani Ceccato \\ Federal University of Health Sciences of Porto Alegre, Brazil \\ Jeam Marcel Geremia \\ Alexandre Mayer \\ Raquel de Oliveira Lupion \\ Marco Aurélio Vaz \\ Federal University of Rio Grande do Sul, Porto Alegre, Brazil
}

\begin{abstract}
Lumbar stabilization is important in high performance rowing due to the high incidence of low back pain. The purpose of this study was to evaluate the lumbar stabilizers muscles performance during an exercise of spinal segmental stabilization and in lumbar multifidus muscle thickness in rowing athletes trained and untrained for this exercise. Nine rowers trained with lumbar stabilization (TLS) and eight rowers without training (CON) participated in the study. Lumbar stabilization performance and multifidus muscle thickness were measured during a maximal voluntary isometric contraction. Lumbar stabilization performance was higher $(p=0.015)$ in the TLS (mean $18.38 \pm 8.00 \mathrm{mmHg}$ ) compared to the $\operatorname{CON}(9.31 \pm 4.91 \mathrm{mmHg})$ group. Muscle thickness variation was higher $(p=0.023)$ in the TLS $(6.92 \% \pm 3.98)$ compared to the CON $(2.81 \% \pm 1.40)$ group. Lumbar stabilization training is an efficient clinical tool to strengthen lumbar muscles and may help to prevent low back pain in rowers.
\end{abstract}

Keywords: spinal stabilization, multifidus, rowing, prevention

Resumo - “Avaliação dos multífidos lombares em atletas do remo durante exercício de estabilização vertebral.” A estabilização lombar é fundamental em esportes de alto rendimento como o remo, devido a elevada incidência de lombalgia. O objetivo do presente estudo foi avaliar o desempenho dos músculos estabilizadores lombares e a espessura do músculo multífido lombar durante um exercício de estabilização segmentar vertebral em remadores. Nove remadores treinados com exercícios de estabilização lombar (TLS) e oito remadores destreinados (CON) foram avaliados. O desempenho dos músculos estabilizadores lombares e a espessura dos músculos multífidos foram mensurados durante uma contração voluntária isométrica máxima. O desempenho foi maior $(p=0,015)$ no grupo TLS $(18,38 \pm 8,00 \mathrm{mmHg})$ quando comparado ao grupo $\operatorname{CON}(9,31 \pm 4,91 \mathrm{mmHg})$. A variação da espessura muscular foi maior $(p=0,023)$ no grupo TLS $(6,92 \% \pm 3.98)$ quando comparado com o grupo CON $(2,81 \% \pm 1,40)$. Treinamento de estabilização lombar é uma ferramenta clínica eficiente para fortalecimento da musculatura lombar e pode auxiliar na prevenção de lombalgia em remadores.

Palavras-chave: estabilização vertebral, multífidos, remo, prevenção

Resumen - "Evaluación del multifidus lumbar en los atletas de remo durante el ejercicio en la estabilización de la columna vertebral." La estabilización lumbar es fundamental en la práctica de deportes como el remo de alto rendimiento, donde la lumbalgia aparece con frecuencia. El objetivo de este estudio fue evaluar el rendimiento de los músculos estabilizadores lumbares, así como el espesor del músculo multifido lumbar, durante un ejercicio de estabilización espinal segmentaria lumbar (una contracción isométrica voluntaria máxima) en atletas de remo. Fueron evaluados nueve remadores sometidos a entrenamiento con ejercicios de estabilización lumbar (TLS) y ocho sin este adiestramiento (CON). El rendimiento fue mayor $(p=0,015)$ en el grupo TLS $(18,38 \pm 8,00 \mathrm{mmHg})$ e comparación con el grupo CON $(9,31 \pm 4,91 \mathrm{mmHg})$. Variación del espesor muscular fue mayor $(p=0,023)$ en el grupo TLS $(6,92 \% \pm 3,98)$ en comparación con el grupo CON $(2,81 \% \pm 1,40)$. El entrenamiento lumbar es una herramienta clínica eficiente para el fortalecimiento de la musculatura lumbar e puede auxiliar en la prevención de lumbalgias en remadores.

Palabras clave: estabilización espinal; multifidos, remo y prevención. 


\section{Introduction}

High performance rowing is a sport with a high level of overload to the trunk, and the cause of lower back pain that frequently appears as the second most frequent injury complaint by rowers (Comerford \& Mottram, 2001). During rowing, the force magnitude at the lumbar spine is substantial. In $70 \%$ of the training cycle, rowers remain with the trunk flexed. The combination of this flexed position with compressive forces at the vertebrae has been identified as one of the likely mechanisms for lumbar spine injury (Rumball, Lebrun, Di Ciacca, \& Orlando, 2005).

Several factors can contribute to overload and low back pain in competitive rower athletes (Caldwell, Mcnair, \& William's, 2003; Reid \& Mcnair, 2000; Rumball et al., 2005; Teitz, O'Kane, \& Lind, 2002). Spine extensors muscle fatigue, usually associated with large volume and training intensity, reduces the contractility of muscle fibers, which can lead to an excessive lumbar flexion and increased stress on spinal structures.

Thus, spinal stability is necessary to reduce stress and depends on integrating two muscle systems: local and global. The global muscular system (consisting of the rectus abdominal, external obliques and the thoracic part of iliocostalis lumbar) when activated, leads to an overall stability of the trunk, but is not able to directly influence specific spinal segments. The local muscle system (comprised of the multifidus, psoas major, quadratus lumborum, lumbar portion of the lumbar iliocostalis, longissimus, transversus abdominis, posterior fibers of the diaphragm and internal oblique) acts directly on the lumbar spine and is responsible for providing segmental stability and directly control the lumbar segments (Bergmark, 1989; Panjabi, 1989).

These stabilizing muscles should be very fit, especially in athletes with overload at the spine. In clinical practice of sports physiotherapy, co-contraction of synergistic muscle groups (transversus abdominis and multifidus) can be evaluated and followed via functional tests such as, abdominal pressure or pressure biofeedback unit (PBU) (Garnier et al., 2009; Mills, Taunton, \& Mills, 2005). The PBU test is a reliable and valid clinical instrument to assess deep abdominal muscle function and/or performance during an abdominal wall contraction (Cynn, Oh, Kwon, \& Yi, 2006; Garnier et al., 2009; Mills et al., 2005; Richardson, Jull, Toppenberg, \& Comerford, 1992; Storheim, Pederstad, \& Jahnsen, 2002). Mills et al. (2005) used the PBU test to evaluate the effect of a 10-week training program on lumbo-pelvic stability in volleyball and basketball female athletes. The athletes presented improvements on the lumbo-pelvic stability after training, showing evidence that the PBU test is an important and effective tool in the evaluation of lumbo-pelvic stability.

Studies (Costa, Maher, Latimer, Hodges, \& Shirley, 2009; Dickx, Cagnie, Parlevliet, Lavens, \& Danneels, 2010; Hall, Tsao, Macdonald, Coppieters, \& Hodges, 2009; McEvoy, Cowling, Fulton, \& Williams, 2008) showed evidence of hypotrophy or atrophy of the transversus abdominis and multifidus muscles on the side of low back pain. These studies report a decrease in contractile performance of these muscles, emphasizing the importance of strengthening of deep abdominal muscles (Koppenhaver, Hebert, Parent, \& Fritz, 2010; Mcgregor, Bull \& Byng-Maddick, 2004; Mills et al., 2005).
Assuming that low back pain arises from a poor spinal segmental stabilization (Dickx et al. 2010; Hides, Stanton, Mendis, \& Sexton, 2011), the aim of this study was to evaluate the changes in PBU and the lumbar multifidus muscle thickness during a segmental spinal stabilization exercise in trained and untrained rowing athletes. The multifidus muscle group was chosen due to the following reasons: (1) the possibility of simultaneous measurements of ultrasound and abdominal pressure with subjects in the prone position; (2) the ease of access to these muscles (posterior region) (Hides, Richardson, \& Jull, 1998); (3) the synergism found between strengthening of transversus abdominis and multifidus muscles (Lehman, Story, \& Mabee, 2005).

Therefore, our expectation was that subjects trained in lumbar stabilization (TLS) would have a larger change in multifidus muscle thickness during the maximal voluntary contraction in the PBU test as an adaptation to the strength training of these synergistic muscles responsible for spinal stabilization compared to the untrained $(\mathrm{CON})$ group.

\section{Methods}

\section{Study design}

The present study is an ex post facto and correlational study. All procedures were approved by the ethics committee and participants signed an informed consent to participate in the study.

\section{Participants}

The population of the present studied included $80 \%$ of the population of rowing athletes in junior and youth categories of Rio Grande do Sul State. Within this population, sixteen healthy male rower athletes (with no history of injury, lumbar spondylolisthesis, spondylolysis, lumbar disc herniations or protrusions, or any previous surgical treatment) were evaluated. The study included only rowing athletes with a minimum of two years of training.

The athletes were divided into two groups: the group trained in lumbar stabilization (TLS) consisted of eight athletes undergoing weekly training sessions to strengthen deep abdominal and back muscles (transversus abdominis and multifidus) for more than two years, whereas the non-trained or control group $(\mathrm{CON})$ consisted of eight untrained athletes in lumbar stabilization. The study included only athletes who were enrolled on daily training ( 3 to 4 hours of rowing a day) and participating in competitions.

\section{Segmental spinal stabilization training}

All athletes belonging to the TLS group performed the same training program. Sessions lasted 45 minutes and were held once a week, before starting physical training. The strengthening exercises for the stabilizing muscles of the spine were taught by the same physiotherapist, and were standardized according to the evolution of preventive training. The sessions began with stabilization exercises in the prone position, progressing to sitting and 

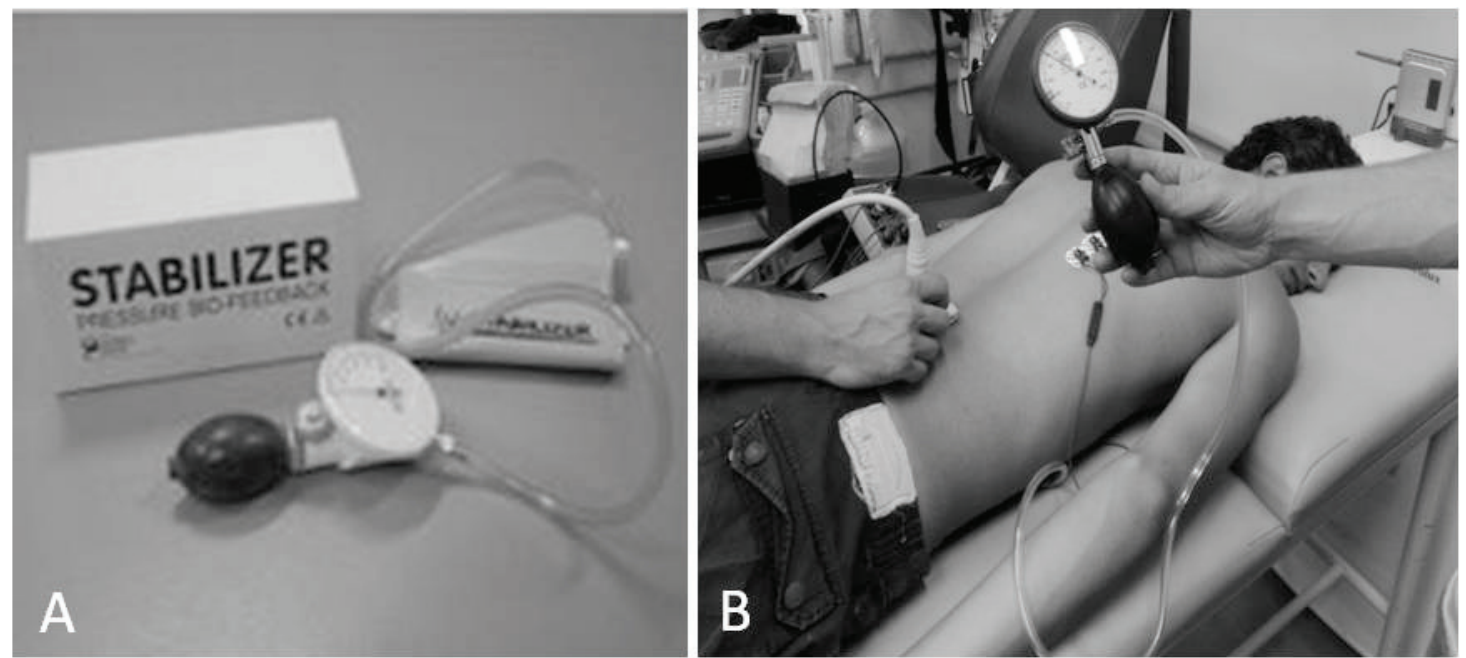

Figure 1. Stabilizer equipment (A) used during the Pressure Biofeedback Unit (PBU) test used to assess lumbar spine stabilization (B).

standing positions. Muscle contractions were performed with emphasis on the expiratory phase of the respiratory cycle. The athlete was asked to inspire by inflating the abdomen and during the exhale, to tighten the abdomen, pulling the navel towards the back, aiming at the formation of a pelvic belt (Richardson et al., 1992; Richardson \& Jull, 1995). Athletes performed four different exercises per session, with 20 repetitions from each exercise, one-minute intervals between trials and five-minute intervals between exercises. Muscle contractions were emphasized to be performed with emphasis on the expiratory phase of the respiratory cycle. The sessions began with stabilization exercises in the prone position, progressing to sitting and four contact support positions (see below). In the first exercise subjects laid prone in the same position depicted in Figure 1B. In the second exercise subjects laid on their back, with knees flexed and upper limbs resting besides the trunk. In the third exercise subjects sat on the floor with hips abducted, knees flexed and feet plants facing each other. For the first three exercises each trial consisted of a maximal voluntary isometric contraction of the abdominal wall muscles lasting about ten seconds with four seconds in the inhalation phase and six seconds for the expiratory phase. In the fourth exercise subjects flexed their shoulders and hips, while maintaining the elbows extended and wrists hyper-extended and knees flexed in the prone position, supported in their hand palms and knees (four contacts prone position). The exercise consisted to contract the abdominal wall muscles while simultaneously flexing the shoulder (with elbow extended) and extending the contralateral hip and the knee. Subjects performed these movements alternating sides, with 10 repetitions for each side. All sessions were supervised by the same physiotherapist, and the unwanted movements during the exercises were observed and corrected.

\section{Lumbar stabilizer muscles performance}

The lumbar stabilizer muscles performance was obtained by means of the PBU test (Stabilizer, Chattanooga Group, Australia; Figure 1A). The athletes were positioned prone with the Stabilizer under the abdomen, in the region located between the anterior superior iliac spines and centered relative to the navel (Figure 1B). The Stabilizer was inflated to a pressure of $70 \mathrm{mmHg}$ and the athletes were instructed to inhale and, during expiration, were asked to contract the abdomen as much as possible as if they were pulling the navel towards the back. During the exercise, the reduction in abdominal pressure over the Stabilizer was registered during four seconds within 10 -second period (Garnier et al., 2009). The larger the reduction in pressure on the Stabilizer was considered the capacity of the athlete to produce spinal segmental stabilization (Garnier et al., 2009; Richardson \& Jull, 1995).

In order to avoid any interference on the results during the voluntary contraction of the abdominal wall muscles, athletes were asked to: (1) empty their bladder before they started the test; (2) not consuming food at least two hours before testing; (3) not perform any abdominal strengthening exercise on the day of the test. This methodology was similar to that of a previous study (Storheim et al., 2002).

\section{Muscle thickness variation}

Simultaneously with the variation in abdominal pressure measurement, the multifidus muscle thickness was assessed. The linear array probe (sampling frequency $=7.5 \mathrm{MHz}$ ) was positioned longitudinally and unilaterally (Figure $1 \mathrm{~B}$ ) following the parameters of the study by Van, Hides and Richardson (2006). The thickness was measured on the dominant side of each athlete, at the L4-L5 level, with an ultrasound machine (Aloka SSD 4000, Tokyo, Japan, sampling frequency $=45 \mathrm{~Hz}$ ).

After palpation, the spinous processes of L4 and L5 were marked on the skin. The athlete was positioned prone with the head relaxed to one side (left or right). Next, the probe was positioned in the approximate direction of the muscle fibers and laterally to the spinous processes. The measures were made at rest and during maximal voluntary contraction of the abdominal wall muscles during the stabilization exercise described above. 


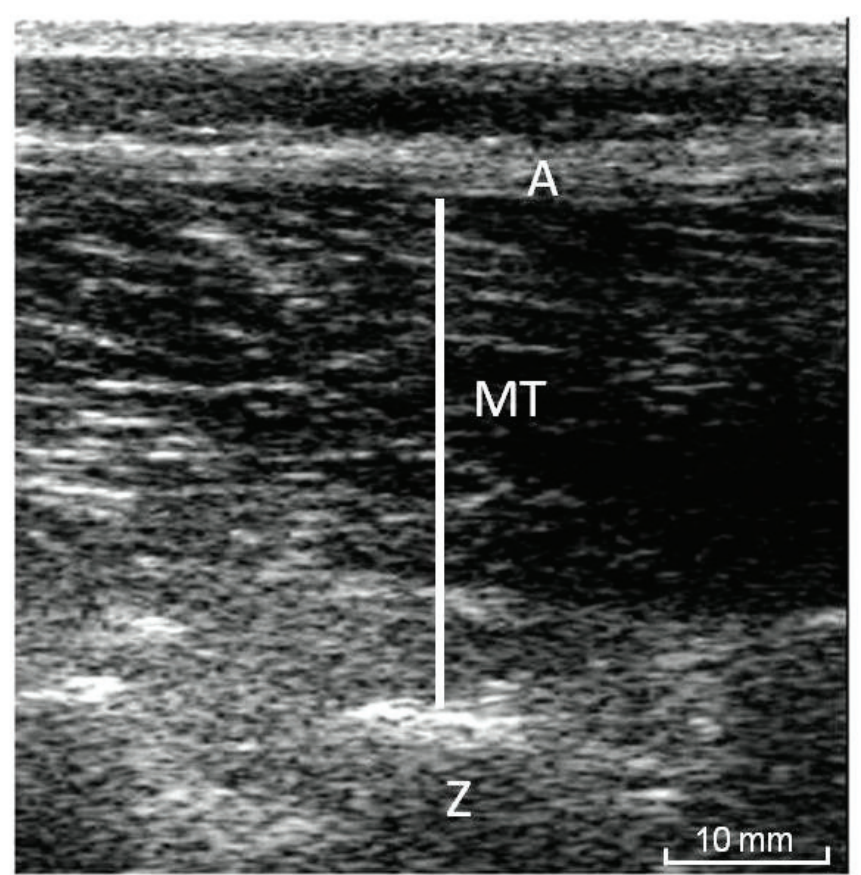

Figure 2. Ultrasound image of the multifidus muscle thickness. $Z=L 4-5$ zygapophyseal joint; $\mathrm{A}=$ aponeurosis; MT: multifidus muscle thickness.

\section{Data analysis}

The abdominal pressure was obtained directly by reading the values on the Stabilizer display. To obtain the values of muscle thickness, the evaluation followed the same methodology described elsewhere (Van et al., 2006). The multifidus thickness (Figure 2) was measured from the tip of the L4-5 zigapophyseal joint to the superior border of the superficial aponeurosis (superior border of the multifidus muscle). The equation used to calculate the variation in muscle thickness was as follows: [(thickness in contraction - thickness at rest) / thickness at rest $\mathrm{x} 100 \%]$.

The Shapiro-Wilk test was used to test the normality of the data. Age, height, body mass, abdominal pressure and changes in multifidus muscle thickness were compared between the groups (trained and untrained) using an independent Student t-test. Data were analyzed using the Sigma Plot Program (version 11) with a significance level set to $\alpha=0.05$.

\section{Results}

Athletes of the CON group had a mean age of $18.38 \pm 5.10$ years, height of $1.78 \pm 0.6 \mathrm{~m}$, body mass of $75.89 \pm 7.32 \mathrm{~kg}$ and body mass index (BMI) of $23.79 \pm 1.35 \mathrm{~kg} / \mathrm{m}^{2}$. The TLS group had a mean age of $16.50 \pm 2.67$ years, height of $1.83 \pm 0.62 \mathrm{~m}$, body mass of $71.88 \pm 8.00 \mathrm{~kg}$ and BMI of $21.44 \pm 1.76 \mathrm{~kg} / \mathrm{m}^{2}$. No difference was found in age $(p=0.372)$, height $(p=0.139)$ and body mass $(p=0.313)$. The BMI was higher $(p=0.010)$ in the CON group compared to TLS group.

Table 1 shows the PBU and the variation in lumbar multifidus muscle thickness values of both groups. The PBU
Table 1. Results (mean \pm SD) for the Pressure Biofeedback Unit (PBU) test and for the variation in multifidus muscle thickness $(\triangle \mathrm{MT})$ in the control (CON) and trained in lumbar stabilization (TLS) groups.

\begin{tabular}{lccc}
\hline & $\begin{array}{c}\text { CON } \\
(\mathbf{n}=8)\end{array}$ & $\begin{array}{c}\text { TLS } \\
(\mathbf{n}=8)\end{array}$ & $\begin{array}{c}\boldsymbol{p} \\
\text { value }\end{array}$ \\
\hline PBU (mmHg) & $9.31 \pm 4.91$ & $18.38 \pm 8.00$ & $\mathbf{0 . 0 1 5}$ \\
$\Delta$ MT (\%) & $2.81 \pm 1.40$ & $6.92 \pm 3.98$ & $\mathbf{0 . 0 2 3}$ \\
\hline
\end{tabular}

values were higher in the TLS group compared to CON group $(p=0.015)$. The TLS group showed a mean variation exceeding $50 \%$ of that of the CON group's average. The variation in lumbar multifidus muscle thickness was higher $(p=0.023)$ in the TLS compared to the CON group.

Figure 3 illustrates the multifidus thickness obtained at rest (Figures $3 \mathrm{~A}$ and $3 \mathrm{C}$ ) and during the maximal abdominal voluntary isometric contraction during the PBU test of an individual from the CON group (with small variations in thickness) and from an athlete of TLS group (with high thickness variation; Figures 3B and 3D), respectively.

\section{Discussion}

Spinal functional stability is dependent of both the local and global muscle integration systems (Bergmark, 1989). When spinal dysfunctions are present, there is a combination of normal movement restriction and compensations to maintain spinal stability. Training of the local stabilizing muscles is necessary to maintain proper alignment of the spine and to establish a stable base of support for body movement (Comerford \& Mottram, 2001).

In sports such as rowing, there is a high demand of the trunk, and training the spinal stabilizing muscles might help in decreasing the risk for spinal injury. Although global muscle strengthening is important, a strong pelvic belt should be emphasized in rowing athletes to protect their spine during high performance training, as it may help to avoid spinal pain and/or injury.

A decrease in contractile performance of the multifidus muscle has been reported in patients with low back pain (Barker et al., 1989; Costa et al., 2009; Lee et al., 2006). If so, subjects with low back pain should have more difficulty in contracting this muscle, and therefore should present a smaller muscle thickness and also a smaller capacity to produce structural changes (i.e. changes in muscle thickness) when going from the resting state to a maximal effort condition.

A similar reasoning could be used when comparing trained and untrained subjects in spinal functional stability. Untrained subjects should present a smaller capacity to change muscle thickness from rest to full effort. The higher variation (6.31\%) of lumbar multifidus muscle thickness in TLS agrees with this idea, and is similar to the results from a previous study (Wilke, Wolf, Claes, Arand, \& Wiesend, 1995) which reported that the lumbar multifidus promoted more than two thirds of the rigidity in the L4-L5 segment. The greatest variation in 

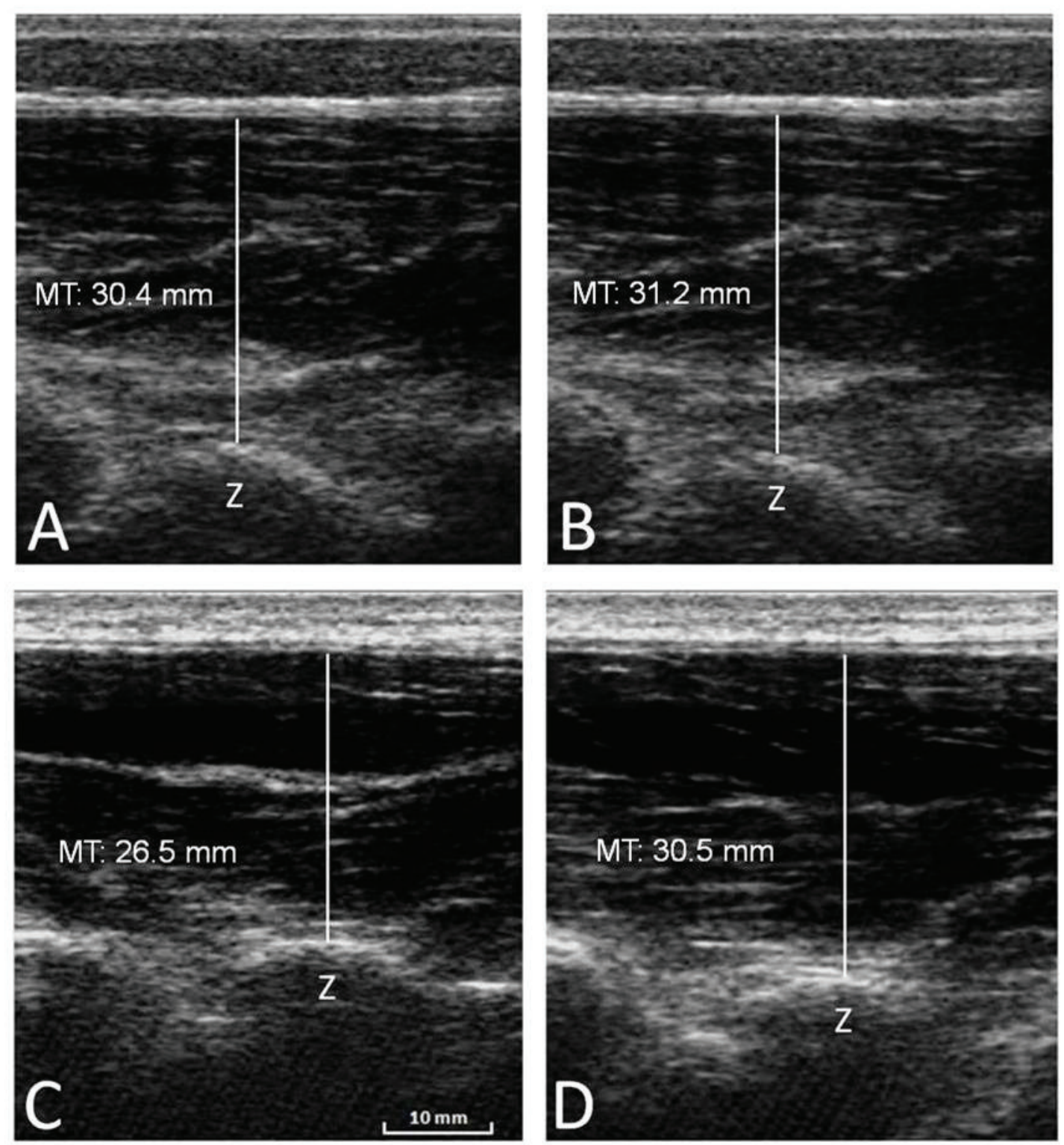

Figure 3. Ultrasound images of the multifidus muscle at rest $(A, C)$ and during the PBU test $(B, D)$ of a representative athlete from the CON $(A, B)$ and from the TLS (C,D) groups, respectively. $\mathrm{Z}$ = zygapophyseal joint; MT = multifidus muscle thickness.

abdominal pressure, observed in TLS group (more than 50\% higher compared to the CON group), is also evidence that trained athletes in lumbar stabilization have a greater capacity of lumbar spine stabilization. The above results confirmed our initial hypothesis that rowers participating on a low back pain prevention program would show a greater variation in abdominal pressure and a greater variation in multifidus thickness during spinal stabilization exercise compared to untrained athletes.

These results may help in the understanding of spinal functional stabilization. In other words, the strengthening of the transversus abdominis and multifidus muscles increases the muscular thickness, improving the lumbar stabilization (Van et al., 2006). In addition, the exercises used in our strengthening program may help to avoid the incidence of excessive loads on skeletal tissues in this region, protecting the lumbar region from injury. However, due to the few studies that we were able to find in this area with a population of rowing athletes, further longitudinal studies are necessary in order to better evaluate if strengthening training programs of abdominal muscles may really act effectively in the prevention of back injury in rowing athletes.

\section{Conclusion}

Rowing athletes trained on segmental spinal stabilization exercises showed great variation in abdominal pressure and in multifidus thickness during maximal effort. These results suggest that stabilization exercises for low back pain in young rowing athletes may help to decrease the injury risk due to sports training thereby reducing the incidence of low back pain in rowers. 


\section{References}

Barker, K. L., Shamley, D. R., \& Jackson, D. (2004). Changes in the cross-sectional area of multifidus and psoas in patients with unilateral back pain. Spine, 29(22), 515-519. Retrieved from http:// journals.lww.com/spinejournal/toc/2004/11150

Bergmark, A. (1989). Stability of the lumbar spine. A study in mechanical engineering. Acta Orthopedic Scandinavic Supplement, 60(230), 5-54. Retrieved from http://www.ncbi.nlm.nih.gov/ pubmed/2658468

Caldwell, J. S., Mcnair, J. P., \& William's, M. (2003). The effects of repetitive motion on lumbar flexion and rector spinae muscle activity in rowers. Clinical Biomechanics, 18(8), 704-711. Retrieved from: http://www.sciencedirect.com/science/article/pii/ S0268003303001177

Comerford, M.J. \& Mottram, S.L. (2001). Functional stability re-training: principles and strategies for managing mechanical dysfunction. Manual Therapy, 6(1), 3-14. Retrieved from: http://www. ncbi.nlm.nih.gov/pubmed/11243904

Costa, L. O. P., Maher, C. G., Latimer, J., Hodges, P. W., \& Shirley, D. (2009). An investigation of the reproducibility of ultrasound measures of abdominal muscle activation in patients with chronic non-specific low back pain. European Spine Journal, 18(7), 1059-1065. Retrieved from: http://www.ncbi.nlm.nih.gov/pmc/articles/PMC2899591

Cynn, H. S., Oh, J. S., Kwon, O. Y., Yi, \& C. H. (2006). Effects of lumbar stabilization using a pressure biofeedback unit on muscle activity and lateral pelvic tilt during hip abduction in sidelying. Archives of Physical Medicine and Rehabilitation, 87(11), 1454-1458. Retrieved from: http://www.ncbi.nlm.nih.gov/pubmed/17084119

Dickx, N., Cagnie, B., Parlevliet, T., Lavens, A., \& Danneels, L (2010). The effect of unilateral muscle pain on recruitment of the lumbar multifidus during automatic contraction. An experimental pain study. Manual Therapy, 15(4), 364-369. Retrieved from http:// www.ncbi.nlm.nih.gov/pubmed/20207187

Garnier, K., Köveker K., Rackwitz, B., Kober, U., Wilke, S., Ewert, T., \& Stucki, G. (2009). Reliability of a test measuring transverses abdominis muscle recruitment with a pressure biofeedback unit. Physiotherapy, 95(1), 8-14. Retrieved from http://www.ncbi.nlm. nih.gov/pubmed/19627680

Hall, L., Tsao, H., Macdonald, D., Coppieters, M., \& Hodges, P. W. (2009). Immediate effects of co-contraction training on motor control of the trunk muscles in people with recurrent low back pain. Journal of Electromyography and Kinesiology, 19(5), 763773. Retrieved from http://www.sciencedirect.com/science/article/ pii/S1050641107001708

Hides, J. A., Richardson, C. A., Jull, G. A. (1998). Use of real-time ultrasound imagining for feedback in rehabilitation. Manual Therapy, 3(3), 125-131. Retrieved from http://www.sciencedirect.com/ science/article/pii/S1356689X98800027

Hides, J., Stanton, W., Mendis, M., \& Sexton, M. (2011). The relationship of transversus abdominis and lumbar multifidus clinical muscle tests in patients with chronic low back pain. Manual Therapy, 16, 573-7

Koppenhaver, S. L., Hebert, J. J., Parent, E. C., \& Fritz, J.M. (2009). Rehabilitative ultrasound imagining is a valid measure of trunk muscle size and activation during most isometric sub-maximal contractions: a systematic review. Australian Journal of Physiotherapy, 55(3), 153-169. Retrieved from http://www.ncbi.nlm.nih. gov/pubmed/19681737

Lee, S., Chan, C.K., Lam, T., Lam, C., Lau, N., Lau, R. W., \& Chan, S. (2006). Relationship between low back pain and lumbar multifidus size at different postures. Spine, 31(19), 2258-2262. Retrieved from http://journals.lww.com/spinejournal/toc/2006/09010
Lehman, G. J., Story, S., \& Mabee, R. (2005). Influence of static lumbar flexion on the trunk muscles response to sudden arm movements. Chiropractic and Osteopathy, 13(23),1-5. Retrieved from http:// www.ncbi.nlm.nih.gov/pmc/articles/PMC1315330

Mcevoy, P. M., Cowling, A. J., Fulton, I. J., \& Williams, M. T. (2008) Transversus abdominis: changes in thickness during an incremental upper limb exercise test. Physiotherapy Theory and Practice, 24(4), 265-273. Retrieved from http://informahealthcare.com/doi/ abs/10.1080/09593980701773340

Mcgregor, A. H., Bull, A. M., \& Byng-Maddick, R. (2004). A comparison of rowing technique at different stroke rates: a description of sequencing, force production and kinematics. International Journal of Sports Medicine, 25(6), 465-470. Retrieved from https://www. thieme-connect.com/DOI/DOI?10.1055/s-2004-820936

Mills, J. D., Taunton, J. E., \& Mills, W. A. (2005). The effect of a 10 -week training regimen on lumbo-pelvic stability and athletic performance in female athletes: a randomized-controlled trial. Physical Therapy in Sport, 6(2), 60-66. Retrieved from http:// www.sciencedirect.com/science/article/pii/S1466853X05000386

Panjabi, M., Abumi, K., Duranceau, J., \& Oxland, T. (1989). Spinal stability and intersegmental muscle forces. A biomechanical model. Spine, 14(2), 194-200. Retrieved from http://www.ncbi.nlm.nih. gov/pubmed/2922640

Reid, D. \& Mcnair, P. (2000). Factors contributing to low back pain in rowers. British Journal of Sports Medicine, 34(5), 321-322. Retrieved from http://www.ncbi.nlm.nih.gov/pubmed/11049136

Richardson, C. A., Jull, G. A., Toppenberg, R., \& Comerford, M. (1992). Techniques for active lumbar stabilization for spinal protection: a pilot study. Australian Journal of Physiotherapy, 38(2), 105-112. Retrieved from http://ajp.physiotherapy.asn.au/AJP/ vol_38/2/AustJPhysiotherv38i2Richardson.pdf

Richardson, C. A. \& Jull, G. A. (1995). Muscle Control - Pain Control. What exercises would you prescribe? Manual Therapy, 1(1), 2-10. Retrieved from http://www.sciencedirect.com/science/article/pii/ S1356689X85702433

Rumball, J. S., Lebrun, C. M., Di Ciacca, S. R., \& Orlando, K. (2005). Rowing injuries. Sports Medicine, 35(6); 537-555. Retrieved from http://www.ncbi.nlm.nih.gov/pubmed/15974636

Storheim, K., Bo, K., Pederstad, O., \& Jahnsen, R. (2002). Intra-tester reproducibility of pressure biofeedback in measurement of transverses abdominis function. Physiotherapy Research International, 7(4), 239-249. Retrieved from http://www.ncbi.nlm.nih.gov/ pubmed/12528579

Teitz, C., O'kane, J., Lind, K., Bonnie, K. L., \& Hannafin, J. A. (2002). Back pain in intercollegiate rowers. American Journal of Sports Medicine, 30(5), 674-679. Retrieved from http://ajs.sagepub.com/ content/30/5/674.abstract

Van, K., Hides, J. A., \& Richardson, C.A. (2006). The use of real-time ultrasound imaging for biofeedback of lumbar multifidus muscle contraction in healthy subjects. Journal of Orthopaedic Sports Physical Therapy, 36(12), 920-925. Retrieved from http://www. ncbi.nlm.nih.gov/pubmed/17193869

Wilke, H. J., Wolf, S., Claes, L. E., Arand, M., \& Wiesend, A. (1995). Stability increase of the lumbar spine with different muscle groups. A biomechanical in vitro study. Spine, 20(2), 192-198. Retrieved from http://www.ncbi.nlm.nih.gov/pubmed/7716624

\section{Authors' note}

Joseani Ceccato, M.Sc., researcher, affiliated with the Federal University of Health Sciences of Porto Alegre, Brazil. 
Jeam Marcel Geremia, M.Sc. is a Ph.D. student, Exercise Research Laboratory, Federal University of Rio Grande do Sul, Porto Alegre, Brazil.

Alexandre Mayer, M.Sc. is researcher at the Exercise Research Laboratory, Federal University of Rio Grande do Sul, Porto Alegre, Brazil.

Raquel de Oliveira Lupion, B.Sc., is a master's student, Exercise Research Laboratory, Federal University of Rio Grande do Sul, Porto Alegre, Brazil.

Marco Aurélio Vaz, Ph.D., professor, is affiliated with the Exercise Research Laboratory, Federal University of Rio Grande do Sul, Porto Alegre, Brazil.

\section{Corresponding author}

Joseani Ceccato

Clube Grêmio Náutico União, Rua Quintino Bocaiúva, n500, Porto Alegre 90440-050 RS, Brazil.

Phone: 55-51-3025 3929

E-mail: joseanic@ig.com.br

\section{Acknowledgements}

This study was supported by CNPq grant awarded to Marco A Vaz. The authors would like to acknowledge the Clube Grêmio Náutico União and the athletes for their cooperation.

Manuscript received on May 10, 2013

Manuscript accepted on January 28, 2014 